\title{
En musiklärares syn på utvecklingsmöjligheter för estetiska lärprocesser vid lärarutbildningen på Stockholms universitet
}

Maria Pemsel

\section{Stallet - en estetisk välkomnande arbetsmiljö}

Stallet i Frescati Backe på Stockholms Universitet $(\mathrm{SU})^{\mathrm{r}}$ inbjuder till ett gränsöverskridande transdisciplinärt arbete. När du kommer in i Stallet möts du av nydesignade vackra ljusa ateljéliknande lokaler med god akustik specifikt designade för estetisk verksamhet. ${ }^{2}$ I miljön samsas vanliga föreläsningssalar med salar anpassade för de olika estetiska ämnena musik, bild, drama och dans. Det finns ett rymligt kök, en studio som är tänkt som en flexibel arbetsyta och det finns en foajé där det går att samla många personer. Där möts vi kring olika typer av festligare sammankomster, utställningar, konserter och till vardags fungerar foajén som allrum för studenterna.

De lärarstudenter vi estetlärare mött i olika estetiska strimmor ${ }^{3}$ eller i ämnesdidaktiska inriktningar ${ }^{4}$ känner sig hemma i Stallet. Allt som oftast kommer studenter och lånar gitarrer eller hämtar något bildmaterial när de arbetar i kurser som blivit förlagda till föreläsningssalarna i Stallet. Det kan vara i en kurs som inte är inriktad specifikt mot estetiska lärprocesser, däremot finns i kursen enskilda lärarstudenter som fått upp ögonen för någon estetisk uttrycksform och som använder sig av estetiska uttryck spontant och med självklarhet genom sin lärarutbildning när möjlighet ges.

Hur du refererar till det här kapitlet:

Pemsel, M. 20I8. En musiklärares syn på utvecklingsmöjligheter för estetiska lärprocesser vid lärarutbildningen på Stockholms universitet. I: von Schantz, U., Thorgersen, K. and Lidén, A. (red.) De estetiska ämnenas didaktik Utmaningar, processer och protester. Pp. 73-93. Stockholm: Stockholm University Press. DOI: https://doi.org/IO.I6993/bap.e. License: CC-BY 
Det är med både glädje och frustration som estetlärargruppen möter studenter utanför erbjudna kurser när de kommer till oss och vill arbeta med estetiska lärprocesser ${ }^{5}$. Det saknas inte vilja hos oss estetlärare att bistå studenter med material eller handleda dem som vill arbeta mer med estetiska lärprocesser i sin utbildning menar jag. Det som saknas är uppdraget att göra det, och framför allt utarbetade former för att kunna erbjuda alla studenter detsamma. Situationen för våra lärarkollegor som är intresserade av att utveckla möjligheter för estetiska lärprocesser i sina ämnen och kurser är densamma. Idag är det ett fåtal lärare som utnyttjar möjligheten att boka in sig i närheten av våra lokaler och som frågar om möjlighet att använda oss, våra estetsalar och vårt material som resurs i undervisningen. Vi som är ämnesansvariga i estetiska ämnen skulle önska att vi hade tid, plats och ekonomiska möjligheter att erbjuda alla lärare och studenter inom lärarutbildningen på SU estetiska upplevelser i samarbete med oss.

I detta kapitel kommer jag som lärare i musikdidaktik att problematisera de ramar den estetiska verksamheten har inom lärarutbildningen på Stockholms Universitet. Först beskrivs det uppdrag de estetiska ämnena idag har gentemot lärarprogrammet och jag använder då några uttryck som används i styrdokument inom skola och lärarutbildning; de estetiska ämnenas didaktik ${ }^{6}$, estetiska strimmor samt estetiska lärprocesser. Sedan belyses behovet av en utbyggd estetisk verksamhet och verkstadsmiljö inom lärarutbildningen med hjälp av citat ur en enkätundersökning. Denna undersökning genomfördes våren $2014^{7}$ med de studenter som vi under läsåret mött i olika kurser och strimmor i Stallet. Kapitlet avslutas med en diskussion kring vilka ramfaktorer som styr oss estetlärare och vilka vi i nuläget kan påverka. Som ett förslag till ett fortsatt forsknings- och utvecklingsarbete målar jag slutligen upp en vision av en öppen estetisk verkstad i Stallet; en mötesplats där ett undersökande och utvecklande arbete med estetiska lärprocesser inom lärarprogrammen kan fortsätta att utvecklas.

\section{De estetiska ämnenas didaktik}

Av de olika uppdrag som den estetiska avdelningen på CeHum ${ }^{8}$ fått efter att den nya lärarutbildningen sjösattes 20 I I kommer den 
största beställningen från Grundlärar-programmet med inriktning mot fritidshem och musik/bild årskurs F-69. Det vi benämner estetiska strimmor beställs från grundlärar- och förskollärarprogrammen och innefattar även ämnena drama och dans. I de estetiska ämnenas didaktik erbjuds forskning, fortbildning, kurser inom VAL- ${ }^{\text {Io }}$ och ULV-projekten ${ }^{\text {II }}$, samt några fristående kurser. Kandidat $^{\mathrm{I2}}$ - och Masterprogram är under uppbyggnad på vår nybildade institution $\mathrm{HSD}^{\mathrm{I}}$.

\section{Grundlärarprogrammet med inriktning mot Fritidshem och musik/ bild årskurs F-6}

På SU är idag de estetiska ämnena musik och bild bäst representerade inom grundlärarprogrammet med inriktning mot arbete i fritidshem. När studenterna söker till utbildningen väljer de en praktisk estetisk inriktning ${ }^{\mathrm{I}}$. I utbildningen får studenterna 2 kurser i ämnesdidaktik om sammanlagt $30 \mathrm{hp}$, kurserna är utlagda under 2 terminen och följs av en ämnesdidaktisk VFU ${ }^{\text {s5 }}$ på $7,5 \mathrm{hp}$. Studenterna blir efter examen behöriga att undervisa i ämnet Bild eller Musik årskurs F-6. Denna utbildning är idag den enda programutbildning förlagd vid SU som har en didaktisk inriktning mot ämnet Bild eller Musik i grundskolan ${ }^{16}$. Övriga lärarprograms musikutbildning, grundlärare årskurs 4-6, 7-9 samt gymnasielärarutbildning i musik, är förlagda till Kungl. Musikhögskolan i Stockholm ${ }^{17}$, Bildlärarutbildningen är på motsvarande sätt förlagd till Konstfack ${ }^{18}$.

De studenter som söker sig till grundlärarprogrammet med inriktning mot arbete i fritidshem och musik årskurs F-6 har väldigt olika förkunskaper. För att bli antagen till utbildningen krävs särskild högskolebehörighet, men det finns inget specificerat krav på ämneskunskap i varken Musik eller Bild. Det innebär i praktiken att det inte ens ställs krav på betyget godkänt=E i estetiska ämnen från grundskolan. Min erfarenhet som lärare i musikdidaktik på utbildningen är att studenter med en bakgrund i eget musicerande från kulturskola, studieförbund eller estetiska program, har relativt lätt att ta till sig och omsätta ämnesdidaktiska didaktiska teorier. De studenter som inte har någon erfarenhet av praktiskt musicerande kommer under utbildningen att påbörja en musikalisk resa i "brant uppförsbacke", som inte kommer att 
vara avslutad när de tar examen. När de startar utbildningen är de i stort behov av baskurser i sång och spel som dessvärre inte ingår i grundlärarutbildningen ${ }^{19}$. I mötet med behöriga VFUhandledare på fältet får vi bekräftat att våra svagaste studenter är i akut behov av fristående kurser för att klara musikläraryrket, om de tänker sig arbeta som lärare i musik årskurs F-6. Ett flertal studenter säger att de inte har några som helst planer på att "bli musiklärare”, de vill bli fritidslärare och endast använda sig av musik i fritidshemspedagogiken. Det är naturligtvis ett sätt att på ett individuellt plan lösa problemet, men det är oroande att dessa studenter i sin examen får en automatisk lärarlegitimation i ämnet musik årskurs F-6 med både rätt att undervisa och att sätta betyg. Min största farhåga är att de som nyexaminerade lärare, trots sina intentioner att välja huvudanställning på fritidshemmet, kan komma att utnyttjas av systemet och tvingas att undervisa $\mathrm{i}$ ämnet i skolan med "för lite på fötterna".

Med en blick i backspegeln på lärarutbildningar i Sverige finns flera tidigare utbildningsreformer som gett lärare behörighet för undervisning i många ämnen i grundskolan trots en obetydlig ämnesspecifik utbildning. Idag är kunskapskraven i estetiska ämnen i LGR I I jämförelsevis höga och det skapar stora problem för svaga studenter på utbildningens ämnesdidaktiska VFU, där det finns högre krav från verkligheten de ska ut och undervisa i, än antagningen till den lärarutbildningen de går på.

Jag vill stryka under att det är av största vikt att universitetet tar ansvar för att yrkesgruppen vi utbildar, med ett ben i fritidshemmet och ett ben i skolan, överlever i yrket. Jag anser att universitetet behöver erbjuda såväl fortbildningskurser som fristående kurser, samt se över möjligheten att utveckla preparandkurser ${ }^{20}$ för sökande till fritidslärarprogrammet med inriktning mot bild/musik årskurs F-6.

\section{Musikdidaktikens utmaningar}

En av de största didaktiska utmaningarna i musikundervisning i dagens resurssnåla skola är att hantera stora elevgruppers individuella behov. Gruppstorlekar i klassrumsundervisning är en ständigt återkommande diskussion i olika Facebook-grupper och andra Communitys för musiklärare. Många musiklärare vittnar om att 
de trots de tydliga kunskapskraven i LGR I arbetar med helklassundervisning. I såväl sång-, spel- och teoriundervisning krävs individanpassade uppgifter med olika svårighetsgrad på uppgifter och möjlighet till olika arbetstempo. I helklass-ensemblespel, vilket är den vanligaste arbetsformen för musicerande i grundskolans musikundervisning, krävs att musikläraren klarar av att göra en anpassning till såväl gruppen som individen. För att få musiken i klassrummet att svänga och alla elever att uppleva musicerande utifrån sin utvecklingsnivå krävs ett stort musikdidaktiskt kunnande och ett väl utvecklat ledarskap. Backman-Bister ${ }^{21}$ har studerat lärares val av kulturella verktyg i helklass-ensemblespel och i sin avhandling ställer hon sig frågan: Anpassas lärarens val av didaktik till ramarna eller får val av didaktik lärare att söka sig till ramar som passar? Hon diskuterar elevers möjlighet till lärande och menar att det inte finns någon jämlikhet att tala om för elever mellan olika skolor eftersom resurstilldelningen styr möjligheten till lärande.

\section{Estetiska lärprocesser i musikdidaktik}

Det är inte självklart att undervisning i musikdidaktik innehåller estetiska lärprocesser. Det som krävs för att studenterna ska få arbeta med estetiska lärprocesser är att vi lärare dels låter dem arbeta processinriktat men också att examinationsuppgifterna utformas som estetiska lärprocesser. Det kan i musik innebära att studenterna som arbetat med ensemblespel får planera och genomföra en konsert för en vald publik. Studenterna kan också inför seminarium arbeta tillsammans med en viss form för redovisning; som att använda ett visst digitalt verktyg, förbereda och leda en samtalsövning kring kurslitteratur och sedan utvärdera samtalsmetoden, eller planera ett lektionsförlopp samt välja ett moment att lära ut i studentgruppen. Ibland väljer jag som lärare att endast bedöma arbetsprocessen och reflektionen men inte det klingande resultatet. Den enskilda studentens prestation vid en konsert kan innefatta prestige, rampfeber och andra icke-estetiska parametrar som påverkar resultatet och därmed försvårar bedömningsarbetet. Istället bedöms studenternas insats och utveckling på det estetiska planet kontinuerligt under kursens gång vid olika tillfällen och inte enbart vid konsert. Den estetiska lärprocessen 
är kopplad till själva projektet och när projektutvärdering och reflektion sker såväl individuellt som i grupp kan det bidra till att nya lärdomar dras. I en musikkurs står det formulerat i betygskriterierna på följande sätt:

För att uppnå betyget E ska studenten kunna:

-planera och genomföra repetitioner och uppspel med ensemble samt bedöma egen medverkan och det gemensamma resultatet -analysera samt reflektera kring egna och andras didaktiska ställningstaganden i relation till musikdidaktisk litteratur och gällande styrdokument

(HVMIFR:s betygskriterier EXo3 ochEXo4) $)^{22}$

Studenterna får under sin musikdidaktiska utbildning vid SU arbeta i studentarbetslag och ensembler med viss lärarhandledning. I ensemblespel synliggörs studiekamraters varierade kunskapsnivåer och musikaliska färdigheter vilket gör individanpassningar av arrangemang nödvändiga. Studenterna får i ensemblespelet tillfälle att problematisera såväl individanpassning som nivågruppering och utifrån egen erfarenhet utveckla sitt musikdidaktiska tänkande kring kommande elevgruppers olika kunskapsnivåer i ämnet. För att utveckla sitt ledarskap får studenterna öva sig i att leda varandra i sångövningar och instudering av enstämmig och flerstämmig körsång vid schemalagda arbetspass för körsångslabborationer. Under hela studietiden för studenterna en egen loggbok i $\mathrm{Mondo}^{23}$ där de reflekterar kring sin egen utveckling i instrumentalspel, musikteori, körsång och ensemblespel.

För att ett projektarbete ska vara lärorikt är efterarbetet i form av egen reflektion och utvärdering viktigt för såväl elever som lärare framhåller Malmberg ${ }^{24}$. I sin österrikiska studie om lärande genom musikprojekt visar hon att all projektformad undervisning kräver reflektion efter avslutat projekt och hon menar att det generellt ges för lite tid till efterarbete i skolors verksamhet. Konserter har en tendens att läggas så sent som möjligt i en kurs för att kunna jämställas med sluttentamen. För att musikelever ska kunna ta till vara sina lärdomar och utveckla dem till generell kunskap krävs lärarstyrd utvärdering och reflektion. Om dessa uteblir stannar kunskapen i det specifika projektet, varnar 
Malmberg. I en svensk språkstudie om högskolestudenter och innehållet i deras dialog under grupparbeten ser Malmbjer ${ }^{25}$ tydligt vikten av lärares handledning under hela arbetsprocessen. För att grupparbeten ska vara effektiva och lärorika i högskolestudier behövs en tydlig handledning, målstyrning, och struktur enligt hennes studie. Hon varnar för att samtal om uppgiftstolkning och grupprocess annars får för stort tidsutrymme på bekostnad av arbete med uppgiftens innehåll och syfte. Loughran ${ }^{26}$ betonar att en aktiv didaktisk reflektion om såväl högskolelärarens handledning, som lärarstudenternas reflektion under och efter projektarbete är avgörande för att didaktisk kunskap ska uppstå.

\section{Estiska strimmor - estetiska lärprocesser i lärarutbildningen}

I de olika lärarprogrammen riktade mot lägre åldrar (årskurs F-6) ger idag HSD olika "strimmor" som innehåller arbete med estetiska lärprocesser. De kan ses som kortare injektioner av musik-, bild-, dans- och dramaundervisning i den utbildning som annars är ganska fattig på estetiska lärprocesser (enligt studenternas svar i enkäten vars resultat beskrivs längre fram i texten). Strimmorna är intensiva seminarieserier i estetiska uttrycksformer, där studenterna möter en palett av estetiska ämnen i olika kombinationer under kortare perioder. Seminarieserierna tänkta att vara transdisciplinära eller multimodala och erbjuder studenterna viss erfarenhet av arbete med estetiska lärprocesser. I de kursvärderingar vi ämneslärare genomför i samband med våra intensiva men korta möten med studenterna får vi ofta höra/läsa att innehållet är intressant och viktigt för det yrke de utbildas för. När vi berättar för studenterna att strimman är det enda inplanerade möte med oss och våra ämnen i utbildningen blir de allt som oftast förvånade och upprörda. Många studenter ifrågasätter programmens struktur och efterfrågar i detta sammanhang fristående kurser i estetiska ämnen utöver det planerade programinnehållet.

När studenterna får smak på arbete med estetiska lärprocesser, vilket ofta inträffar i samband med våra strimmor av estetisk verksamhet, skulle i den bästa av världar lärarutbildningen vid studenternas hemvistinstitutioner ta vid. Arbetet skulle kunna 
fortsätta i andra programkurser där estetiska lärprocesser planeras in i uppgifter och examinationer. Detta görs säkert i enskilda fall av lärare men inte med tydlig systematik och övergripande planering.

\section{Hinder för estetiska lärprocesser}

Vilka tänkbara hinder finns för att lärare ska använda sig av estetiska lärprocesser och låta dem genomsyra lärarutbildningen? I Diskursiva legitimeringar av estetisk verksambet i lärarutbildningen beskriver forskarna Lindgren \& Ericsson ${ }^{27}$ universitetslärares syn på förändringar i den numera akademiserade lärarutbildningen, samt vilka olika effekter det fått för estetisk verksamhet inom lärarutbildningen. Jag vill ringa in två huvudområden som också lyfts fram i Lindgren \& Ericssons studie, det ena är begränsade ekonomiska resurser för kurser och det andra är upplevd bristande kompetens eller dåligt självförtroende hos universitetslärare.

Ett praktiskt problem kopplat till resurser är införskaffande av material och lämpliga lokaler. För att genomföra grupparbeten och examinationer där estetiska lärprocesser används krävs därför tillgång till estetiska ämnens institutioner där arbetsmaterial och rörelseutrymme finns. Det är inte ekonomiskt försvarbart att varje institution, än mindre varje universitetslärare, har sin egen uppsättning av bildmaterial, musikinstrument, kostymer eller dansytor. Många kurser innehåller få lärartimmar per student och då finns det sällan möjlighet att göra seminarier med fler än en lärare, detta kan vara en anledning att estetlärare inte används i andra ämnens didaktik, eller $\mathrm{UVK}^{28}$-kurser.

Ett annat hinder för arbete med estetiska lärprocesser kan vara en upplevelse av begränsad kompetens hos universitetslärare, detta kan enligt Lindgren \& Ericsson få olika konsekvenser i undervisningen. ${ }^{29} \mathrm{Jag}$ tycker inte det är konstigt om de universitetslärare som saknar utbildning i estetiska ämnen också saknar ämneskunskap om materialanvändning och metoder. Med begränsade ämneskunskaper följer även en osäkerhet inför bedömning av estetiska redovisningar. Fahltin ${ }^{30}$ lyfter i sina studier upp problematiken att lärare i grundskolan använder estetiska lärprocesser men de drar sig för att betygsätta det estetiska resultatet 
vid skolredovisningar på grund av bristande kompetens i ämnet. Detta är beklagligt eftersom det innebär att eleverna lär sig att det estetiska uttrycket inte räknas som väsentlig kunskap i skolan. Här finns det ett behov av en allmän diskussion inom lärarutbildningen om estetiska lärprocessers betydelse och vad en tentamen på universitet kan innebära, hur den kan gestaltas och bedömas.

\section{Intresse av estetisk verksamhet på Stockholms Universitet?}

Vårterminen 20I4 genomfördes en enkätundersökning som en del av mitt FoU-projekt vars målsättning var att undersöka möjligheterna för dåvarande CeHum att öppna en estetisk verkstad för studenter och lärare på de olika lärarprogrammen inom $S^{3}{ }^{3}$. Grundtanken för den öppna verkstaden var att den skulle fungera som ett komplement till de strimmor och kurser som finns i den nuvarande lärarutbildningen. En öppen estetisk verkstad skulle kunna erbjuda handledning i estetiska lärprocesser och workshops, samt ge möjlighet till eget estetiskt arbete i lokalerna. En målsättning för verkstadsarbetet skulle vara att utveckla estetiska lärprocesser på SU till att bli en naturlig arbetsform i alla lärarutbildningar. Inspirationen till upplägget fick jag från Mediaverkstans ${ }^{32}$ sätt att arbeta och genom samtal med engagerade estetlärarkollegor på CeHum.

I början av våren 20I 4 tillfrågades de kollegor som undervisar i Stallet om sin syn på en tänkt estetisk verksamhet i form av en verkstad, samt vilka hinder de kunde se för ett sådant sätt att arbeta. De tillfrågades också om vilka frågor som borde ställas till studenter i våra kurser. Resultatet av deras svar blev en webbenkät jag producerade i Google Drive. Jag nådde med hjälp av kurslärare på CeHum och BUV samtliga studenter som genomgått kurser med estetiska inslag under läsåret 20I3/20I4 via gamla kursrum i Mondo där jag berättade om enkätens syfte. Därefter blev studenterna personligen inbjudna att svara på enkäten via mail under april månad. Uppskattningsvis skickades enkäten ut till drygt 500 studenter och något fler än roo svarade. Här följer en sammanfattning av resultaten tillsammans med några citat som belyser studenternas engagemang. 


\section{Enkätsvaren visar följande:}

En stor del av studenterna från både förskollärarutbildningen och grundlärarprogrammen anser att deras utbildning inte innehåller tillräckligt mycket estetiska kurser och motiverar det utifrån sina kommande yrkesrollers behov:

Väldigt liten del av hela utbildningen består av estetisk verksamhet, men en stor del av yrkeslivet kommer bestå av det.

Med tanke på att arbete med barn består till väldigt stor del av estetiska uttryckssätt borde det vara en central fokus i utbildningen.

De estetiska ämnena har fungerat som ett komplement för alla teorier som vi lär. Det är inte alltid lätt att koppla teori till estetik. Därför tycker jag att det är viktigt att vi făr handla efter teorier i praktiken.

Den kritik som framkommer i de skriftliga kommentarerna är att många estetiska kurser upplevs som korta och grunda. Det efterfrågas uppföljning, fördjupning och valbarhet, men också en tydligare betoning på estetisk verksamhet i alla pedagogiska utbildningar.

Förskolläraryrket innebär konstant estetiskt arbete med barn i alla former. Det är alldeles för lite att trycka in estetiska verkstäder i en enda kurs, visst måste vi läsa mycket teori, men estetik är minst lika viktigt då det är det som används som verktyg i yrket sen. VFU (praktiken) erbjuder oss elever att själva få pröva på att jobba estetiskt men det är inte en självklarhet för alla. Det bör definitivt erbjudas mer estetiskt verksamhet.

5 timmar i bild och musik räcker inte. Och detta bara inom matematik. Varför inte ha estetisk verksamhet i flera ämnen?

All estetisk verksamhet stressas igenom. Kunskaperna underhålls ej under utbildningens gång. Det behövs mer för en fördjupad förståelse som består under och efter utbildningen.

Att förlägga de få timmar i estetik som nu ingår i programmet under andra terminen och sedan inte följa upp detta senare under utbildningen känns minst sagt som en bristande planering.

Många av fritidslärarna är både frustrerade och besvikna på den nivå kurserna på SU håller. De som har obefintliga ämneskunskaper när de går in i utbildningen inser behovet av baskurser: 
Det känns som att det bör finnas ett visst kunskapskrav för att söka till just denna utbildning med musik som inriktning. Det blir för tufft emellanåt att hänga med och verkligen lära sig allt om man inte har baskunskaperna. Varför inte annars lägga in en baskurs för de studenter som känner ett behov av det, för att sedan påbörja med utbildningens "riktiga" kurser?

De studenter som är måna om att uppnå en kunskaps- och färdighetsnivå som räcker till för att undervisa i musik årskurs F-6 vittnar om att ytterligare fördjupning behövs.

Under dessa tre år känns det som att vi har för få/för korta kurser i musik för att man ska känna sig beredd inför kommande yrkesverksamhet. Det är många moment vi endast hinner snudda vid som känns mycket relevanta och som man därför skulle vilja ha mer undervisning $\mathrm{i}$ om det fanns mer tid. I vår utbildning känns det som att det ligger mycket mer fokus på fritidspedagogik än musiken.

På frågan om studenterna ser ett tydligt behov av att arbeta med estetiska lärprocesser i någon specifik kurs, har svaren varierat. Några studenter har ansett det vara svårt att precisera någon kurs.

Jag önskar ha generellt med estetiska läroprocesser i utbildningen som helhet. Kan ej precis namnge någon generell kurs.

Inte i någon speciell utbildning hittills, men allmänt. Jag vill ha mer estetik för att det är en värdefull uttrycksform i sig själv, och inte för att det ska underlätta lärandet av något annat.

Jag vet inte vilken specifik kurs, men skulle vara intressant att få blanda in mer estetik i "vanliga" kurser.

Det finns ingen specifik kurs där jag saknat estetik. Men vissa kurser känns som att man hade kunnat vara utan och istället haft ett estetiskt ämne.

Många informanter har också svarat nej och det kan tolkas som att intresse för estetiska lärprocesser inte är så stor hos alla studenter, en annan tolkning är att de faktiskt inte kan se hur liknande arbetsformer skulle kunna infogas i andra kurser. Bland ja-svaren finns en del mycket konkreta förslag till förändringar av kurser i utbildningen. 
Samtliga kurser skulle må bra av dramapedagogiska övningar. Vår utbildning präglas av en insyn i relationsskapande och utforskande. Hur kan vi lära andra om vi inte upplever det vi känner och lär oss? Bildspråk är också ett verktyg som skulle gagna samtliga kurser. Konkreta kurser som behöver dramaövningar: "Sociala relationer i förskolan, 7.5 hp". Specialpedagogik, 7.5 hp. Etiska samtal förekommer i samtliga kurser på ett eller annat vis. När vi samtalar och diskuterar kring etik, så uppkommer ofta skilda åsikter. DÄR och DÅ är det VIKTIGT att ta till dramapedagogiken.

Bild i form av ateljerista där man kan få lära sig om lera, papperskonst, olika hantverk osv.

Inom exempelvis Pedagogisk dokumentation skulle det vara otroligt bra med estetiska lärprocesser. I och med det skulle man kunna få se mer exakt hur man kan arbeta med det i förskolan.

Det finns också studenter som anser att en del av AUO, numera kallat UVK skulle behöva specialiseras eller estetiseras.

Utbildningen fokuserar mycket på AUO och det gör att jag tappar verklighetsanknytningen till mitt ämne. Ex en kurs i bedömning som då fokuserar mycket på allmän bedömning eller tom de teoretiska ämnena, känns då inte helt givande för en blivande musiklärare.

Vi pratar om hur viktigt det är att lära med alla sinnen så varför inte ta med det estetiska i alla ämnen som vi har?

På frågan om vilka ämnen och vad inom ämnena studenterna skulle vilja få fördjupad kunskap i blev en del studenter nästan förnärmade.

\section{Absurd fråga!}

De verkade tycka att det var självklart att de behövdes fördjupningsmöjligheter:

Ju fler tekniker/arbetssätt jag behärskar desto lättare blir det för mig att ge barnen möjlighet att utforska omvärlden på ett sätt som passar dem.

Handledning/fördjupningskurser inom: Digitala verktyg Foto Tryck, tekniker Lera, mer teknik Material kännedom t ex färger, trä, metall. 
Bild - för att kunna applicera det i ateljén på den förskola där jag jobbar. All materialkunskap, tekniker, utförandesätt, fantasi, projekt! Jag vill läsa om hur barn berättar saker i sina målningar och teckningar. Om ett barn ritar en skilsmässa eller annan upplevelse som kan vara traumatisk - hur bemöter du det pedagogiskt då? Vilka knep tar du till? Hur känner du dig i situationen? Drama inte teater utan åt dramapedagogik - jobba med det magiska som sker när en grupp luckras upp av samarbetsövningar, grupp- processandet, hur drama skapar en grupp på ett FULLSTÄNDIGT annat sätt än vad något annat kan! URVIKTIGT att kunna som pedagog!!

De var lika tydliga med att också kurser i baskunskaper behövs för att repetera men också bredda sina kunskaper

Kunna få lite mer kunskap och bas att kunna stå i.

Ännu fler praktiska exempel på hur man kan arbeta med barnen. Särskilt de områden man själv tidigare inte varit i kontakt med, skulle jag behöva få mer kunskap om. Bara för att jag själv inte är uppvuxen med exempelvis musik ska jag inte beröva barnen den erfarenheten.

Jag tycker det absolut borde finnas valbara kurser i estetiska ämnen, Den gitarrkurs som finns är jättebra, men det kunde även finnas kurser i experimentell musik (prova på fler instrument), barnmusik (sånger och kör). Mer dans skulle också uppskattas.

Jag anser estetiska ämnen vara förlösande och tror att det skulle vara bra att höja estetlärarnas status med ännu mer utbildning.

Några informanter vill också förändra utbildningen i grunden både de estetiska strimmorna men belyser också vinster i ämnesövergripande samarbete mellan lärarprogrammen på SU och ett mer holistiskt tänkande kring universitetsstudierna.

Inom framför allt dans hade det varit bra att få en större koppling till barns estetiska processer. Vi behöver lära känna alla dessa ämnen bättre för att kunna använda dem med säkerhet i förskolan.

Jag finner intresse i att få arbeta ämnesövergripande i praktiken under utbildningen med bildstudenter och även andra estetiska studenter. Vi gör gemensamma gestaltningar i SA- lag som är blandade med bild- och musikstudenter. Men det skulle vara 
givande att under själva musikkursen ha ett moment som berör det ämnesövergripande, med att få göra Powerpoint-presentation och visa för bilden (likaväl de gör det för musikstudenterna) hur vi i musiken vill göra ett projekt och sedan få möjlighet att utforma detta med bildstudenterna. Vi blir som två separata världar under den tid vi går våra inriktningar, varför inte sammanföra oss mer och skapa bra band redan under studietiden? Detta skulle vara intressant att göra även med lärarstudenter i språk och matematik.

Så stor andel som $92 \%$ av de som svarat på enkäten skulle vilja att SU erbjöd fördjupningskurser av olika slag inom det estetiska området. Det finns ett stort intresse för allt ifrån större kurser på 7,5hp, till mindre workshops, samt kvälls- och sommarkurser.

De skriftliga svaren rörande utveckling av en estetisk verkstad likt Mediaverkstan är nästan rörande positiva till att en sådan miljö skapas i Stallet.

\section{Hade varit guld värt!}

Ja det vore perfekt att kunna gå på en öppen estetisk verkstad för att kunna sy ihop det man har behov av och utveckla detta.

Tillgång till handledning inom estetiska ämnen samt inspiration.

HELT FANTASTISKT! ÄNTLIGEN!!!!!! Fortsätt såhär, vi behöver VERKLIGEN detta!

Några av informanterna är realistiska och säger att även om en sådan resurs skulle finnas skulle tidspressen i utbildningen kanske hindra att man utnyttjade den.

Jag läser ett program om 2 Io hp. Det finns gott om rum att få plats med mer estetiska kurser/verkstäder under ordinarie studietid.

Det kanske vore något, men jag undrar om man skulle ha tid att gå dit, då det inte är kurs.

Medieverkstan har varit till stor hjälp. Superbra! Bra idé, men risken är att man inte går dit om det inte är obligatoriskt.

Det vore mycket passande för mig att få möjlighet att ha tillgång till flera kurser, handledningstider, verkstad. Jag har försökt att jobba under loven och det var underbart. Man får inspiration tack vare stämningen och den härliga atmosfären på verkstaden. 
Det finns också kritiska röster till en allmän resurs och som menar att den kanske framförallt gynnar de svagaste studenterna, inte de studenter som vill fördjupa sig.

Mediaverkstaden har under mina år på SU alltid varit ett steg tillbaka i användandet av datorer. Ibland känns det inte riktigt som om den inser vad dagens ungdomar redan kan och ska ha lärt sig i skolan. med det sagt så är det ju en väldigt bra plats för alla de som inte tillhör vår generation, de som kanske har utländsk utbildning osv så jag ser den som en nödvändighet för en högre utbildning öppen för alla. en öppen estetisk verkstad är i min vision snarare en plats för att jobba framåt (än att fylla luckor som annan utbildning borde fyllt). En plats där samarbete över ämnesgränserna underlättas. Workshops eller dylikt har också möjligheterna att utveckla spel och sångteknik i större utsträckning.

Någon understryker också den direkta kopplingen till vad handledning skulle kunna innebära i en fusion mellan digitalteknik och estetik i en och samma verkstad.

Det skulle öppna upp för ett mer naturligt tänk kring de digitala verktygen som det talas mycket om i läroplanen och i kursen. Det är lätt att prata om att vår tids skolor är så digitala, men i verkligheten kanske det inte blir så digitalt för alla nyexaminerade studenter för att de inte fătt ordentligt testa och utvärdera själva. Att få möjlighet att arbeta digitalt när det musiceras, arbeta med musikprogram och inte enbart prata om det på lektionerna skulle vara mer givande. Hur kan musik skapas utan fysiska instrument $i$ musikkursen skulle vara intressant att få ha som uppgift.

Många av ovanstående citat är positiva till den estetiska verksamhet de möter i Stallet och de skall ses som representativa för svaren som kom in. Ett fåtal av svaren var negativa till estetiska ämnen eller uttryckte att det var alldeles tillräckligt med estetiska ämnen i utbildningen. Dessa svar var väldigt fåordiga och därför svårtolkade. Svarsfrekvensen får ses som ett bra resultat i en enkät som är frivillig att svara på. Större delen av studenterna som kontaktades var studenter som avslutat sina kurser och strimmor hos oss. Vad de andra studenterna tänkte och tyckte står osagt liksom skälet till varför de inte svarat. Det som däremot är väldigt 
tydligt är att de som engagerat sig i att svara på enkäten anser att det råder en brist på estetiska ämnen i deras lärarutbildningar i förhållande till vad yrkeslivet kräver.

\section{En öppen estetisk verkstad}

Hur långt bort är då realiseringen av visionen om en öppen estetisk verkstad? Det är ganska tydligt att studenterna önskar sig en öppen estetisk verkstadsmiljö som under vissa tider i veckan skulle kunna erbjuda handledning i studentarbeten, inspirationsföreläsningar, och fortbildningspaket på kvällar, helger och sommarlov. I den nya institutionsbildningen HSD där mediaverkstaden blivit en samarbetspartner ligger vi organisatoriskt ett steg närmare att kunna erbjuda en öppen estetisk verkstadsmiljö för såväl lärare som studenter. Kostnaden är dock inget institutionen kan eller ska bära ensam, så frågan är var på lärarutbildningen en sådan resurs ska budgeteras? En estetisk verkstad som är helt beroende av olika institutioners kursekonomi och beställningar blir både instabil ekonomiskt och styrd innehållsmässigt menar jag. Dessutom finns en risk att öppenheten för den enskilda studentens och lärarens behov kan försvinna i en sådan konstruktion. Det bästa vore om det skulle skapas en resurs centralt för en estetisk verkstad inom lärarutbildningen.

Enkäten som genomfördes 20I 4 visar att många studenter ansåg att det skulle behövas en öppen estetisk verkstad med ett brett kursutbud. I en uppföljande studie under läsåret I 5/I 6 har intervjuer med lärare från olika program genomförts för att komplettera studenternas enkätsvar. Målet med studien var att synliggöra lärarnas behov av en estetisk resurs och möjliga former för den, samt deras syn på ramfaktorer för estetiska lärprocesser inom SU. Urvalet har bestått av lärare som själva haft ett stort intresse av estetiska aktiviteter och som haft lätt att tala om estetiska lärprocesser i undervisning generellt. I studien ser jag tydligt att det finns en didaktisk osäkerhet inför användande av estetiska lärprocesser i undervisningen även bland estetiskt kunniga lärare. Bland de hinder som nämns av lärarna är brist på material och anpassade lokaler. De uttrycker också en frustration kring begränsande kursekonomi. Mina informanters utsagor stämmer 
väl överens med det som Lindgren \& Ericsson fick fram i sin studie. ${ }^{33}$ De flesta lärarna i studien önskar fler möjligheter till kollegiala möten med fokus på konkret kursutveckling. Behovet av en estetisk verkstadsmiljö för undervisning varierar men de flesta ser verkstadsmiljön som ett potentiellt centrum för en estetisk högskolepedagogisk utveckling.

I detta kapitel har det beskrivits hur HSD:s beställningar för estetiska strimmor och ämnesdidaktiska kurser idag ser ut från olika delar av lärarutbildningen och att det saknas ett övergripande uppdrag att utveckla estetiska lärprocesser inom lärarutbildningar. Det finns i nuläget inget centralt formulerat uppdrag att utveckla en estetisk verkstad. Det finns inte från regeringshåll någon uttalad önskan att alla lärarstudenter och lärare ska erbjudas samma möjligheter att utveckla estetiska lärprocesser. Hur skulle ett övergripande estetiskt uppdrag konstrueras på SU och vem skulle skjuta till resursen? Om medel skulle tillföras centralt för estetisk verksamhet kvarstår ändå en ansvarsfråga; vem skulle ta ansvar för att alla studenter i sina respektive utbildningar fick en rättvis del av den relativt kostsamma resurs som skapas?

Ett förändringsarbete pågår inom lärarutbildningen på SU. Behovet av ett samarbete mellan forskning, didaktik och VFU belystes av ledningen vid uppstarten av förändringsarbetet i Aula Magna. Samarbete kring studenterna inom en lärarutbildning behövs i alla former, framförallt eftersom studenterna rör sig mellan flera olika institutioner. I enkäten lyfter studenterna gång på gång behovet av en genomlysning av hela sin programutbildning och en återkommande återkoppling till estetiska arbetsformer. För samarbete mellan lärare och institutioner krävs tid och mötesplatser på alla nivåer. Stallet och den estetiska verkstadsmiljön skulle kunna erbjuda en plats där formella och informella möten mellan såväl studenter som lärare äger rum och där de estetiska lärprocesserna skulle bli den gemensamma nämnaren.

\section{Fundera vidare över...}

I. I detta kapitel presenteras några ramar som styr den estetiska verksamheten vid Stockholms universitet. Vilka ramar styr den verksamhet du deltar i? 
2. I kapitlet skissas en verksamhet som går under arbetsnamnet estetisk verkstad och som är tänkt att vara en miljö för att stimulera, stödja och berika den lärarutbildning som finns idag. En sådan verksamhet kommer troligtvis inte att passa in i gängse system, varken institutionsorganisationer, ekonomiska beräkningar av HÅS och HÅP eller schemaläggning. För att utnyttjandet av en verkstadsmiljö ska bli optimal för alla kommer nya tankesätt och nya sociala mönster i befintlig verksamhet förmodligen att krävas. Hur tänker du att en sådan vision bäst skulle implementeras i den verksamhet där du befinner dig?

3. Studenter vi mötte under läsåret 20I3/20I4 utryckte i enkätsvaren ett missnöje med nuvarande lärarutbildnings upplägg. Missnöjet beskrevs främst som en brist på estetiska inslag i utbildningen men också en önskan till fördjupning utifrån individuella önskemål. Hur påverkar dessa upplevda brister av praktiskt estetiska inslag den nyutexaminerade läraren?

4. I läroplanen för gymnasieskolan GY I I nämns inte begreppet estetiska lärprocesser. På SU beställs i nuläget inga estetiska strimmor på ämneslärarprogrammet som utbildar gymnasielärare med behörighet för grundskolans senare år. Vad får detta för konsekvenser för undervisningen på gymnasiet och av barn i senare åldrar i grundskolan?

\section{Slutnoter}

I. Stallet. http://www.su.se/om-oss/universitetsomr $\% \mathrm{C}_{3} \% \mathrm{~A}_{5}$ det/arki tektur/byggnader/frescatibackehusen-I.I3 8486.Hämtad 20I 6-09-09-05.

2. Rosenbergs arkitekter. https://sv.wikipedia.org/wiki/Rosenbergs_ Arkitekter. Hämtad 2016-09-09-05.

3. Estetiska strimmor. Serier av seminarium i estetiska ämnen som beställs för kurser av andra institutioner, som exempelvis Etik och Estetik, en kurs som ges inom förskollärarutbildningen.

4. Ämnesdidaktisk inriktning. I grundlärarprogrammet med inriktning mot Fritidshem väljer studenterna ett estetiskt/praktiskt ämne som de får behörighet att undervisa i, från årskurs F-6. 
5. Estetiska lärprocesser. Samlingsnamn på de lärprocesser som uppstår i konstnärligt projektarbete.

6. Estetiska ämnens didaktik. Den ämnesspecifika didaktik som varje ämneslärare tillämpar och reflekterar kring i sitt arbete med elever i skolan, som exempelvis musikens didaktik.

7. Intresse av estetisk verksambet på Stockholms Universitet? Webbenkät som genomfördes i samband med SU:s estetutredning (SU FV I.I.2-I364-I5), som en del ett FoU-projekt., som en del ett FoU-projekt.

8. CeHum. Centrum för de Humanistiska och estetiska ämnenas didaktik blev genom en sammanslagning av flera enheter, 20I6. Institutionen för de humanistiska och sambällsvetenskapliga ämnenas didaktik (HSD). http://www.su.se/hsd/

9. BUV. http://www.buv.su.se/utbildning/alla-utbildningar/program/ grundl $\% \mathrm{C}_{3} \% \mathrm{~A}_{4}$ rarprogram-fritidshem. Hämtad 2016-09-05.

Io. VAL. http://www.su.se/lararutbildningar/l\% $\mathrm{C}_{3} \% \mathrm{~A}_{4}$ rare/vidareut bildning-av-1\% $\mathrm{C}_{3} \% \mathrm{~A}_{4}$ rare-val. Hämtad 2016-09-05.

I I. ULV. http://www.su.se/lararutbildningar/l\% $3 \% \mathrm{C}_{4}$ rare/utl $\% \mathrm{C}_{3} \%$ A4ndska-1\% $\mathrm{C}_{3} \% \mathrm{~A}_{4}$ rares-vidareutbildning-ulv.Hämtad 2016-09-09-05.

I 2. http://www.su.se/hsd/om-oss/nyheter/s\% $\mathrm{C}_{3} \% \mathrm{~B} 6 \mathrm{k}$-till-nytt-kandidatprogram-i-estetiska- $\% \mathrm{C}_{3} \% \mathrm{~A}_{4}$ mnens-didaktik-drama-teater-180-hp-I.275343. Hämtad 2016-09-09-05.

I3. Institutionen för de humanistiska och sambällsvetenskapliga ämnenas didaktik (HSD). http://www.su.se/hsd/

I4. Från och med HT2or 6 ges även möjlighet att välja ämnet Idrott och Hälsa i samarbete med GIH. http://www.buv.su.se/utbildning/alla-utbildningar/program/grundl $\% \mathrm{C}_{3} \% \mathrm{~A}_{4}$ rarprogram-fritidshem/ing\% $3 \%$ A 5ng-idrott-h\% $\mathrm{C}_{3} \% \mathrm{~A}_{4}$ lsa-ı. 266368 . Hämtad 2016-09-05.

I 5. VFU. Verksamhetsförlagd Utbildning.

I6. LGRII. http://www.skolverket.se/om-skolverket/publikationer/ visa-enskild-publikation?_xurl_=http $\%_{3} \mathrm{~A} \%{ }_{2} \mathrm{~F} \%{ }_{2} \mathrm{Fwww}$. skolverket.se \% 2Fwtpub\% 2Fws\% 2Fskolbok\% 2Fwpubext\% 2Ftrycksak\%2FRecord ${ }_{3} \mathrm{Fk}_{3}{ }_{3} \mathrm{D} 2575$. Hämtad 2016-09-05. 
I7. KMH. http://www.kmh.se/\% $\mathrm{C}_{3} \% \mathrm{~A}_{4}$ mnesl\% $\mathrm{C}_{3} \% \mathrm{~A}_{4}$ rarprogram. Hämtad 2016-09-05.

I 8. Konstfack. http://www.konstfack.se/Utbildning/Lararutbildning/. Hämtad 2016-09-05.

I9. Fristående kurser i gitarr och piano. Under 2016 gavs 2 fristående kurser på 7,5 hp att ges i grundläggande gitarr och pianospel för undervisningsbruk. Kurserna kan sökas av alla lärarstudenter.

20. Preparandkurser En form av pre-collegekurser, ofta genomförda med andra skolformer som folkhögskolor, kulturskolor. Ett inkluderande verktyg används ofta för att bredda rekryteringen till programmen och för att höja kunskapsnivån hos de sökande.

2I. Backman-Bister, A, 2014.

22. HVMıFR är kurskod för Musik I för Fritidshem och årskurs F-6.

23. Mondo. Namnet på det virtuella klassrum där studenterna kommunicerar med varandra eller sina lärare utanför seminarietid.

24. Malmberg, I, 20I I.

25. Malmbjer, A, 2007.

26. Loughran, J, 2006.

27. Lindgren, M. och Ericsson, C, 20I3, s.7-40.

28. UVK. Undervisningsvetenskaplig kärna tidigare kallat $A U O$ Allmänt Utbildnings- område

29. Lindgren, M. och Ericsson, C, 2013.

30. Falthin, A, 20I I.

3I. Intresse av estetisk verksambet på Stockholms Universitet? Webbenkät som genomfördes i samband med SU:s estetutredning (SU FV I.I.2-I364-I 5), som en del ett FoU-projekt.

32. Mediaverkstan. http://www.su.se/hsd/medieverkstan Hämtad 2016-09-05.

33. Lindgren, M. och Ericsson, C, 2013. 


\section{Referenser}

Backman-Bister, A. 20I4. Spelets regler. En studie av ensembleundervisning $i$ klass. Diss. Stockholm, KMH Förlaget.

Falthin, A. 20 I I. Musik som nav i skolredovisningar. Lic. Stockholm, KMH Förlaget.

Malmberg, I. 20II. Projekmethode und Musikunterricht. Didachtisch- methodische Perspektiven der Projektmetode für Lehr-und Lernprozesse im Musikunterricht. Diss. Studienrichtung Musikpädagogik. Wien: Universitet für Musik und Darstellende Kunst.

Malmbjer, A. 2007. Skilda världar. En språkvetenskaplig undersökning av gruppsamtal som undervisnings- och lärandeform inom högre utbildning. Diss. Stockholm: Uppsala Universitet.

Lindgren, M. och Ericsson, C. 2013. Diskursiva legitimeringar av estetisk verksambet i lärarutbildningen. Educare - Vetenskapliga skrifter $\mathrm{I}(\mathrm{I})$ : ss. $7-4 \mathrm{O}$.

Loughran, J. 2006. Developing a Pedagogy of Teacher Education. London: Routledge. 